\title{
Phototoxic Assesment of Polycyclic Aromatic Hydrocarbons by Using NIH-3T3 and L-929 Cell Lines
}

\author{
Varun Tobit ${ }^{*}$, O. P. Verma1, P. W. Ramteke ${ }^{1}$ and R. S. Ray ${ }^{2}$ \\ ${ }^{1}$ Department of Molecular Biology \& Cellular Engineering, Jacob School of Biotechnology and Bioengineering, Sam Higginbottom Institute of Agriculture, Technology and \\ Sciences, Naini, Allahabad, Uttar Pradesh, India \\ ${ }^{2}$ Indian Institute of Toxicology Research, Lucknow (U.P) India
}

\begin{abstract}
The Polycyclic Aromatic Hydrocarbons (PAHs) are the most widespread organic environmental pollutants. PAHs are found in motor vehicle exhaust. Some PAHs are found in medicines, dyes, plastics, pesticide, naphthalene balls and wood preservatives. The compounds under the presences of Sun light generally activated and inhibited the cell growth. Hence the present investigation was focused on the maintenances and culturing of NIH-3T3 and L-929 cell lines derived from mouse fibroblast as well as the phototoxicity assessment of PAHs compounds (Benzo(a) pyrene, Pyrene) in these cell lines. Monolayer culture of cell lines was grown in DMEM culture medium. Live cells were attached in cryovial check surface and dead cell was mixed in the medium and rise up on the upper layer on the medium. The result showed that the singlet oxygen $\left({ }^{1} \mathrm{O}_{2}\right)$ generation by benzo(a)pyrene and pyrene showed the phototoxicity at various concentration from $5-50 \mathrm{ppm}$ under the exposure of UV-A $(5.76 \mathrm{~J} / \mathrm{cm} 2), \mathrm{UV}-\mathrm{B}(2.16 \mathrm{~J} / \mathrm{cm} 2)$ and sunlight $60 \mathrm{~min}$. Rose Bengal $(50 \mathrm{ppm})$ was used as the positive control. Pyrene generated the more amount of singlet oxygen as compared to Benzo(a)pyrene while Benzo(a)pyrene generated more superoxide as compared to Pyrene.
\end{abstract}

Keywords: Phototoxicity; Cell lines; Benzo(a)pyrene and Pyrene

\section{Introduction}

Phototoxicity is a form of photosensitivity that is not depended on an immunologic response. Phototoxic reaction are dose dependent and will occur in almost anyone who takes or applies an adequate amount of the offending agent and UVR, but the dose necessary to induce such reaction varies among individuals. Phototoxicity causes sunburn, blisters, and other skin problems. Photoreactive agents or photosensitizers are chemicals that induce a photoreaction. The chemicals may be therapeutic, cosmetic, industrial, or agricultural [1]. Photosensitivity reactions can be caused by injected, oral, or topically applied chemical photosensitizers. Photosensitivity reactions can occur in exposure to both UVA and UVB, but are more likely to occur in the UVA range [2]. PAH can be thought of as marker molecules as their abundance can be directly proportional to combustion processes in the region and therefore directly related to air quality.

\section{Materials and Methods}

\section{Chemicals used}

Dimethyl Sulphoxide (DMSO), Dulbecco's Minimal Essential Medium (DMEM) with Earle's Salt, Sodium Bicarbonate, Nutrient Broth, Nutrient Agar.

\section{Generation of singlet oxygen $\left({ }^{1} \mathrm{O}_{2}\right)$}

The generation of singlet oxygen by UVR/sunlight exposed or unexposed $\mathrm{PAH}$ under aerobic condition was measured in aqueous solution. A $10 \mathrm{ml}$ assay mixture containing RNO $\left(0.35 \times 10 \mathrm{M}^{-5 s}\right.$ to $0.4 \times 10 \mathrm{M})$ and L-histidine $(10 \mathrm{M})$ in $0.01 \mathrm{M}$ phosphate buffer $(\mathrm{pH}$ 7.4) in each petridish was exposed under similar set of experimental conditions for comparison. The production of singlet oxygen was measured spectrophotometrically by recording the bleaching of $\mathrm{RNO}$ at $440 \mathrm{~nm}$. The production of singlet oxygen was confirmed by an addition of specific quenchers of singlet $\left(\mathrm{NaN}_{3} / \mathrm{DABCO}\right)$ in the reaction mixture. The concentration of each $\mathrm{PAH}$ was $25 \mathrm{ppm}, 50 \mathrm{ppm}$, $75 \mathrm{ppm}$ and $100 \mathrm{ppm}$ and dose level of the exposures were as follows:
UVA irradiation- $1.4 \mathrm{mw} / \mathrm{cm}$, UVB $0.4 \mathrm{~mW} / \mathrm{cm}$ and sunlight for $1 \mathrm{hrs}$.

\section{Generation of superoxide anion radical}

The formation of superoxide radical was assessed by monitoring the photosensitized reduction of NBT. The reduction of NBT by superoxide leads to formation of a blue colored NBF (Nitro-blue diformazoan). A $10 \mathrm{ml}$ assay mixture-containing NBT $(1.67 \mathrm{x} 10 \mathrm{M})$ in $0.01 \mathrm{M}$ carbonate buffer (pH10) and a PAH was irradiated for 0 to 20 min under UVA, UVB or sunlight. The production of NBF was monitored by recording an increase in the absorbance spectrophotometrically at $560 \mathrm{~nm}$. The generation of superoxide was further confirmed by an administration of SOD (25 Units $/ \mathrm{ml}$ ) in a reaction system as a selective quencher. The concentration of a PAH was $25 \mathrm{ppm}, 50 \mathrm{ppm}, 75 \mathrm{ppm}$ and $100 \mathrm{ppm}$ and exposure doses of UVA, UVB and sunlight exposure were $1.4 \mathrm{~mW} / \mathrm{cm}$, $0.4 \mathrm{~mW} / \mathrm{cm}$ and 0 to $20 \mathrm{~min}$ respectively.

\section{Photodegradation of PAH'S}

The $10 \mathrm{ppm}$ solutions of each compound prepared in DMSO were taken for the phodegradation study. The $10 \mathrm{ml}$ solution of each compound was taken in $60 \times 15 \mathrm{~mm}$ glass petridish and irradiated synergistically under UVA $\left(1.4 \mathrm{~mW} / \mathrm{cm}^{2}\right)$ and UVB $\left(0.4 \mathrm{~mW} / \mathrm{cm}^{2}\right)$ for different time intervals (30, 60, 90, 120, 150 and $180 \mathrm{~min})$. After exposure the sample was transferred in graduated test tubes and loss of volume

${ }^{*}$ Corresponding author: Varun Tobit, Sam Higginbottom Institute of Agriculture Technology and Sciences, Naini, Allahabad, Uttar Pradesh, India, E-mail: tobit01231@gmail.com

Received April 10, 2011; Accepted May 09, 2011; Published May 13, 2011

Citation: Tobit V, Verma OP, Ramteke PW, Ray RS (2011) Phototoxic Assesment of Polycyclic Aromatic Hydrocarbons by Using NIH-3T3 and L-929 Cell Lines. J AIDS Clinic Res 2:123. doi:10.4172/2155-6113.1000123

Copyright: (c) 2011 Tobit V, et al. This is an open-access article distributed under the terms of the Creative Commons Attribution License, which permits unrestricted use, distribution, and reproduction in any medium, provided the original author and source are credited. 
due to evaporation was make up by DMSO and absorption spectrum of was taken between 200-700 nm by Cintra 40 spectrophotometer.

\section{Bacterial culture}

E. coli (DH5a): E. coli is one of the main species of bacteria living in the lower intestines of mammals, known as gut flora. When located in the large intestine, it actually assists with waste processing, vitamin $\mathrm{K}$ production, and food absorption.

Colony Forming Unit (C.F.U.): After incubation period, the growth of bacterial colonies was counted.

\section{Survivability}

1. Effect of UV-A Radiation $\left(1.4 \mathrm{~mW} / \mathrm{cm}^{2}\right)$ on growth of E.coli. UV-A exposure to E.coli for 0-2 hours did not produce any significant change in cfu of E.coli. On the other hand, exposure upto 3 hour produced significant reduction in the E.coli.

\section{Effect of UV-B radiation $\left(0.4 \mathrm{~mW} / \mathrm{cm}^{2}\right)$ on growth of E.coli.}

UV-B exposure to E.coli for 0-1 hour did not produce any significant change in cfu of E.coli. On the other hand, no growth was observed on 90 min of exposure.

\section{Results and Discussion}

The singlet oxygen $\left({ }^{1} \mathrm{O}_{2}\right)$ generation by Benzo (a) pyrene showed at different concentration from 25 to $100 \mathrm{ppm}$ (Table 1a) under the exposure of UV-A $\left(5.76 \mathrm{~J} / \mathrm{cm}^{2}\right), \mathrm{UV}-\mathrm{B}\left(2.16 \mathrm{~J} / \mathrm{cm}^{2}\right)$ and Sunlight $(60$

\begin{tabular}{|c|c|c|c|}
\hline $\begin{array}{c}\text { Concentration } \\
\text { (PPM) }\end{array}$ & $\begin{array}{c}\text { UV-A }(\mathbf{2 . 0} \mathbf{~} \mathbf{W} / \\
\left.\mathbf{c m}^{2}\right)\end{array}$ & $\begin{array}{c}\text { UV-B(0.5 } \mathbf{~ m W /} \\
\mathbf{c m}^{2} \mathbf{)}\end{array}$ & Sunlight \\
\hline 25 & 0.039 & 0.045 & 0.185 \\
\hline 50 & 0.087 & 0.099 & 0.221 \\
\hline 75 & 0.110 & 0.126 & 0.242 \\
\hline 100 & 0.142 & 0.143 & 0.386 \\
\hline
\end{tabular}

Table 1 (a): Generation of singlet oxygen in benzo (a) pyrene on exposing in UV-A, UV-B, and Sunlight for $1 \mathrm{hr}$.

\begin{tabular}{|c|c|c|c|}
\hline $\begin{array}{c}\text { Concentration } \\
\text { (PPM) }\end{array}$ & $\begin{array}{c}\text { UV-A(2.0 } \mathbf{~ m W /} \\
\mathbf{c m}^{\mathbf{2}} \mathbf{)}\end{array}$ & $\begin{array}{c}\text { UV-B(0.5 } \mathbf{~ m W /} \\
\mathbf{c m}^{\mathbf{2}} \mathbf{)}\end{array}$ & Sunlight \\
\hline 25 & 0.210 & 0.201 & 0.701 \\
\hline 50 & 0.124 & 0.195 & 0.684 \\
\hline 75 & 0.373 & 0.392 & 0.892 \\
\hline 100 & 0.600 & 0.412 & 0.876 \\
\hline
\end{tabular}

Table 1 (b): Generation of singlet oxygen in pyrene on exposing in UV-A, UV-B, and Sunlight for $1 \mathrm{hr}$.

\begin{tabular}{|c|c|c|c|}
\hline $\begin{array}{c}\text { Concentration } \\
\text { (PPM) }\end{array}$ & $\begin{array}{c}\text { UV-A(2.0 } \mathbf{~} \mathbf{W} / \\
\mathbf{c m}^{2} \text { ) }\end{array}$ & $\begin{array}{c}\text { UV-B(0.5 } \mathbf{~ m W / ~} \\
\mathbf{c m}^{\mathbf{2}} \text { ) }\end{array}$ & Sunlight \\
\hline 25 & 0.170 & 0.159 & 0.197 \\
\hline 50 & 0.455 & 0.309 & 0.437 \\
\hline 75 & 0.690 & 0.384 & 0.424 \\
\hline 100 & 0.511 & 0.360 & 0.097 \\
\hline
\end{tabular}

Table 2 (a): Generation of superoxide in benzo(a)pyrene on exposing in UV-A UV-B, and Sunlight for $20 \mathrm{mins}$.

\begin{tabular}{|c|c|c|c|}
\hline $\begin{array}{c}\text { Concentration } \\
\text { (PPM) }\end{array}$ & $\begin{array}{c}\text { UV-A(2.0 } \mathbf{~} \mathbf{W} / \\
\mathbf{c m}^{\mathbf{2}} \text { ) }\end{array}$ & $\begin{array}{c}\text { UV-B(0.5 } \mathbf{~ m W /} \\
\mathbf{c m}^{2} \mathbf{)}\end{array}$ & Sunlight \\
\hline 25 & 0.033 & 0.053 & 0.071 \\
\hline 50 & 0.093 & 0.132 & 0.138 \\
\hline 75 & 0.154 & 0.209 & 0.183 \\
\hline 100 & 0.182 & 0.277 & 0.223 \\
\hline
\end{tabular}

Table 2 (b): Generation of superoxide in pyrene on exposing in UV-A, UV-B, and Sunlight for 20 mins.
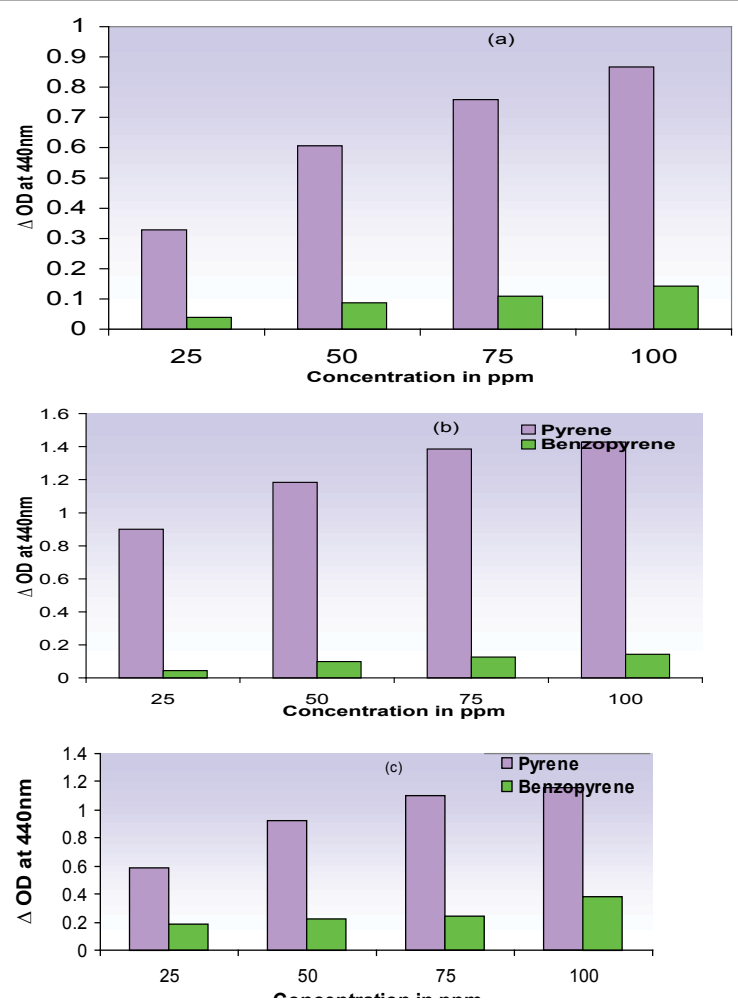

Figure 1: $a, b$, and $c$ shows the generation of singlet oxygen radical in pyrene and benzopyrene on exposing them to UV-A, UV-B and sunlight.

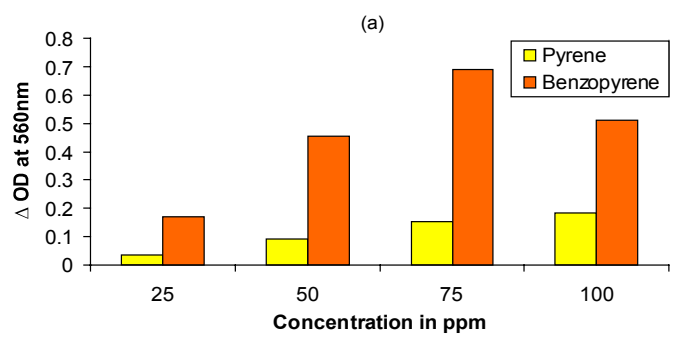

(b)

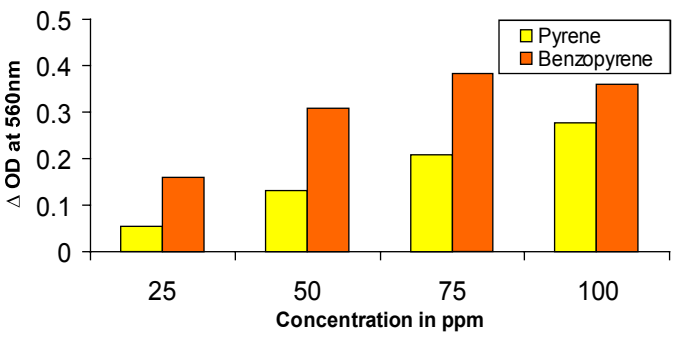

(c)

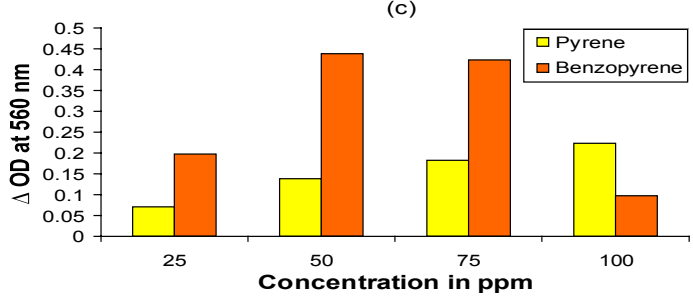

Figure 2: a,b,and c shows the generation of superoxide radical in pyrene and Benzopyrene. 


\begin{tabular}{|c|c|c|c|}
\hline $\begin{array}{c}\text { Concentration } \\
\text { (PPM) }\end{array}$ & $\begin{array}{c}\text { UV-A(2.0 } \mathbf{~} \mathbf{W} / \\
\mathbf{c m}^{2} \text { ) }\end{array}$ & $\begin{array}{c}\text { UV-B(0.5 } \mathbf{~} \mathbf{W} / \\
\mathbf{c m}^{2} \text { ) }\end{array}$ & Sunlight \\
\hline 25 & 0.170 & 0.159 & 0.197 \\
\hline 50 & 0.455 & 0.309 & 0.437 \\
\hline 75 & 0.690 & 0.384 & 0.424 \\
\hline 100 & 0.511 & 0.360 & 0.097 \\
\hline
\end{tabular}

Table 3: Generation of superoxide in benzopyrene on exposing in UV-A, UV-B, and Sunlight for 20 mins.

\begin{tabular}{|c|c|c|}
\hline SI.No. & Exposure & No. of Colonies \\
\hline 1. & 0 & $83 \times 104$ \\
\hline 2. & 30 minutes & $70 \times 104$ \\
\hline 3. & 60 minutes & $56 \times 104$ \\
\hline
\end{tabular}

Table 4: Effect of UV- A Radiation $\left(1.4 \mathrm{~mW} / \mathrm{cm}^{2}\right)$ exposure on E. coli growth.

\begin{tabular}{|c|c|c|}
\hline SI.No. & Exposure & No. of Colonies \\
\hline 1. & 0 & $83 \times 104$ \\
\hline 2. & 30 minutes & $65 \times 104$ \\
\hline 3. & 60 minutes & $30 \times 104$ \\
\hline
\end{tabular}

Table 5: Effect of UV- B Radiation $(0.4 \mathrm{~mW} / \mathrm{cm} 2)$ exposure on E.coli growth.

\begin{tabular}{|c|c|c|c|c|}
\hline $\begin{array}{l}\text { UV exposure } \\
\text { (dose) }\end{array}$ & $\mathbf{1 0} \mathbf{~ p p m}$ & $\mathbf{1 0 0} \mathbf{~ p p m}$ & $\mathbf{5 0 0} \mathbf{~ p p m}$ & $\mathbf{1 0 0 0} \mathbf{~ p m}$ \\
\hline $\begin{array}{c}\text { UV-A (1.4mW/ } \\
\left.\mathrm{cm}^{2}\right)\end{array}$ & 6.0 & 7.0 & 7.7 & 8.1 \\
\hline $\begin{array}{c}\text { UV-B (0.4mW/ } \\
\left.\mathrm{cm}^{2}\right)\end{array}$ & 4.3 & 4.8 & 5.0. & 5.5 \\
\hline $\begin{array}{c}\text { UV exposure } \\
\text { (dose) }\end{array}$ & $\mathbf{1 0} \mathbf{~ p p m}$ & $\mathbf{1 0 0} \mathbf{~ p p m}$ & $\mathbf{5 0 0} \mathbf{~ p p m}$ & $\mathbf{1 0 0 0} \mathbf{~ p p m}$ \\
\hline $\begin{array}{c}\text { UV-A (1.4mW/ } \\
\left.\mathrm{cm}^{2}\right)\end{array}$ & 6.0 & 7.0 & 7.7 & 8.1 \\
\hline
\end{tabular}

Table 6: Inhibition zone at different concentration of Rose Bengal on E.coli on exposing to UV-A, UV-B and sunlight.

\begin{tabular}{|c|c|c|c|c|}
\hline $\begin{array}{c}\text { UV exposure } \\
\text { (dose) }\end{array}$ & $\mathbf{1 0} \mathbf{p p m}$ & $\mathbf{1 0 0} \mathbf{~ p p m}$ & $\mathbf{5 0 0} \mathbf{~ p p m}$ & $\mathbf{1 0 0 0} \mathbf{~ p p m}$ \\
\hline $\begin{array}{c}\text { UV-A (1.4mW/ } \\
\left.\mathrm{cm}^{2}\right)\end{array}$ & 5.4 & 6.0 & 6.5. & 7.5 \\
\hline $\begin{array}{c}\text { UV-B }(0.4 \mathrm{~mW} / \\
\left.\mathrm{cm}^{2}\right)\end{array}$ & No & 4.4 & 4.8 & 5.0 \\
\hline Dark & No & No & No & No \\
\hline
\end{tabular}

Table 7: Inhibition zone at different concentration of pyrene on exposing to UV-A, UV-B and sunlight.

\begin{tabular}{|c|c|c|c|c|}
\hline $\begin{array}{c}\text { UV exposure } \\
\text { (dose) }\end{array}$ & $\mathbf{1 0} \mathbf{~ p p m}$ & $\mathbf{1 0 0} \mathbf{~ p p m}$ & $\mathbf{5 0 0} \mathbf{~ p p m}$ & $\mathbf{1 0 0 0} \mathbf{~ p p m}$ \\
\hline $\begin{array}{c}\text { UV-A (1.4mW/ } \\
\left.\mathrm{cm}^{2}\right)\end{array}$ & 5.5 & 6.0 & 6.3 & 7.0 \\
\hline $\begin{array}{c}\text { UV-B }(0.4 \mathrm{~mW} / \\
\left.\mathrm{cm}^{2}\right)\end{array}$ & No & 4.3 & 4.5 & 4.9 \\
\hline Dark & No & No & No & No \\
\hline
\end{tabular}

Table 8: Inhibition zone at different concentration of Benzo(a) pyrene on exposing to UV-A, UV-B and sunlight.

min). Rose Bengal (50 ppm) was used as the positive control. In case of Benzo (a) pyrene UV-A showed the concentration dependent ${ }^{1} \mathrm{O}_{2}$ generation but the order of ${ }^{1} \mathrm{O}_{2}$ generation in UV-B and sunlight was mixed. Highest yield of ${ }^{1} \mathrm{O}_{2}$ was observed under sunlight and lower yield was observed by UV-B (Figure 1).

The singlet oxygen $\left({ }^{1} \mathrm{O}_{2}\right)$ generation by Pyrene showed at different concentration from 25 to $100 \mathrm{ppm}$ (Table $1 \mathrm{~b}$ ) under the exposure of UV-A $\left(5.76 \mathrm{~J} / \mathrm{cm}^{2}\right)$, UV-B $\left(2.16 \mathrm{~J} / \mathrm{cm}^{2}\right)$ and Sunlight $(60 \mathrm{~min})$. Lowest yield of ${ }^{1} \mathrm{O}_{2}$ generation was observed in $25 \mathrm{ppm}$ and the highest yield was observed at $40 \mathrm{ppm}$ concentration. Rose Bengal (50 ppm) was used as the positive control. Pyrene is more toxic as compared to Benzo(a)pyrene in presence of sunlight. Sunlight exposure showed the maximum ${ }^{1} \mathrm{O}_{2}$ generation in all concentration (Figure 1).

The superoxide was generated $\mathrm{O}_{2}$ by benzo (a) pyrene under UV-A $\left(5.76 \mathrm{~J} / \mathrm{cm}^{2}\right)$ and UV-B $\left(2.16 \mathrm{~J} / \mathrm{cm}^{2}\right)$ exposure. Different concentration from $25 \mathrm{ppm}$ to $100 \mathrm{ppm}$ (Table 2a) of Benzo(a)pyrene were used for superoxide generation. Highest yield of superoxide was observed under UV-A $\left(0.690 \mathrm{~mW} / \mathrm{cm}^{2}\right)$ and UV-B $\left(0.384 \mathrm{~mW} / \mathrm{cm}^{2}\right)$ at $75 \mathrm{ppm}$ while sunlight showed maximum generation of superoxide (0.437) at concentration $50 \mathrm{ppm}$ (Figure 2).

\section{Inhibition zone at different concentration}

The MTT Assay showed by using NIH 3T3 and L-929 cell lines under UV-A $\left(5.76 \mathrm{~J} / \mathrm{cm}^{2}\right)$, exposure for the phototoxicity assessment of Pyrene and Benzo(a)pyrene. The two concentration (25 and 50 ppm) of all PAHs were selected for phototoxicity evalutions. There was no significant reduction of Cell viability in dark at $25 \mathrm{ppm}$ and 50 ppm in Benzo(a)pyrene but pyrene at $50 \mathrm{ppm}$ and the concentration showed decreased in cell viability. The UV exposure showed maximum phototoxic response in Benzo (a) pyrene and minimum was observed in Pyrene while both were showing moderate phototoxicity PAH's may be toxic to human beings and their toxicity may increase further under exposure to UVR/sunlight. We observed that photoexcited Pyrene and Benzopyrene produced significant amount of singlet oxygen $\left({ }^{1} \mathrm{O}_{2}\right)$ and significant amount of superoxide anion radical $\left(\mathrm{O}_{2} .^{-}\right)$at the levels of their usage. The generation of reactive oxygen species (ROS) by these PAH was dependent upon the exposure periods under ambient intensities of UVA, UVB and solar radiation. The formation of the ROS was confirmed by using sodium azide [3] as specific quenchers of ${ }^{1} \mathrm{O}_{2}$ and SOD for $\mathrm{O}_{2}$ - $^{-}$respectively. It is well known that ROS produced by various compounds under the influence of ultraviolet/ visible radiation, are responsible to alter the normal function of cellular constituents and skin photosensitization causing erythema or edema [4], tumor promotion [5], mutagenic and carcinogenic effects [6]. Moreover, some Furocoumarins used for the treatment of psoriasis and other skin diseases, are producing ${ }^{1} \mathrm{O}_{2}$ and $\mathrm{O}_{2}$.- under UVA exposure and are known to produce skin photosensitization reactions leading to carcinogenesis [7]. Riboflavin, a known nutritional factor of physiological importance, generated ROS and produced haemolysis to human erythrocytes in vitro under exposure to sunlight [8].

Thus the production of ROS by UVA, UVB and sunlight exposed $\mathrm{PAH}$ suggested that the photoexcited PAH may impose adverse effect to human health. Phototoxicity caused by illuminated PAH may be further induced in many folds by an increase of UV radiation in sunlight due to depletion of ozone layer [1]. Therefore an exposure to UVR/ sunlight should be avoided after intake of Pyrene and Benzopyrene On the basis of earlier studies it was found that UVR and sunlight exposure for $60 \mathrm{~min}$. at different intensities did not affect cell viability. Further exposure for higher time periods, the cell viability was decreased. Therefore Phototoxicity of different PAH was studied at the ambient level of UVA $\left(1.4 \mathrm{~mW} / \mathrm{cm}^{2}\right), \mathrm{UVB}\left(0.4 \mathrm{~mW} / \mathrm{cm}^{2}\right)$ and sunlight (1.4x105 Lux) exposure.

\section{References}

1. Fridovich I (1983). Superoxide radical: an endogenous toxicant. Annu Rev Pharmacol Toxicol 23: 239-257.

2. Zhang AY, Elmets CA (2005) Drug-induced photosensitivity. Available from: 
Citation: Tobit V, Verma OP, Ramteke PW, Ray RS (2011) Phototoxic Assesment of Polycyclic Aromatic Hydrocarbons by Using NIH-3T3 and L-929 Cell Lines. J AIDS Clinic Res 2:123. doi:10.4172/2155-6113.1000123.

Page 4 of 4

URL: http://www.emedicine.com/derm

3. Ouannes C, Wilson T (1968) Quenching of singlet oxygen by tertiary aliphatic amines. Effects of DABCO. Journal of the American Chemical Society 90: 6527-6528.

4. Ichihashi M, Ueda M, Budiyanto A, Bito T, Oka M, et al. (2003) UV-induced skin damage. Toxicology 15: 21-39.

5. Sanders CS, Hamm F, Elsner P, Thiele JJ (2003) Oxidative stress in malignant melanoma and non-melanoma skin cancer. $\mathrm{Br} \mathrm{J}$ of Dermatol 148: 913-922.

6. Nishigori A, Hattori Y, Toyokuni S (2004) Role of reactive oxygen species in skin carcinogenesis. Antioxid Redox Signal 6: 561-570.

7. Pathak MA, Joshi PC (1984) Production of active oxygen species $\left({ }^{1} \mathrm{O}_{2}\right.$ and $\mathrm{O}_{2} .-$ ) by psoralen and ultraviolet radiation (320-400 nm). Biochem Biophys Acta 789: $115-126$

8. Misra RB, Bajpai PK, Joshi PC, Hans RK (2001) An unusual photohaemolytic property of riboflavin. Food Chem Toxicol 39: 11-18. 